\title{
The Effect of Educational Intervention Based on Health Belief Mod- el on Nurses' Stress Management in Intensive Care Units
}

\begin{abstract}
Background and Objective:Stress is one of the main problems of nurses, which greatly affects their professional performance and their personal life and causes conflict between work and life. The purpose of this research was to identify the effects of Health Belief model-based training on nurses' occupational stress. Materials and Methods: This is a Quasi-experimental study conducted on nurses. 45 nurses were randomly selected from special wards of a hospital as the interventional group and also 42 nurses from another hospital were randomly selected as the control group. Data gathering tool was included the Nursing Stress Scale (NSS) for determining nurses' occupational stress and HBM Model constructs questionnaire to determine the effect of educational intervention. Training program was carried out in three 2-hour sessions. Subjects were monitored for 1 month. Statistical analysis was performed before, and 1 month after training using SPSS software. Statistical tests including Chi- Square, independent t-test, Paired t- test, KolmogorovSmirnov were used in this study.

Results: Mean NSS score of the intervention group reduced from $107.311 \pm 20.800$ to $89.578 \pm 23.352$ after the training. Moreover, after training, the variables of perceived susceptibility, perceived severity, perceived benefits, cue to action, self-efficacy, and behaviors showed a significant increase and perceived barriers decrease in the intervention group compared to the control group $(P<0.05)$.

Conclusion: Results showed that the Health Belief Model for stress management education was effective in the reduction of nurses' stress level. Considering that behavioral and non-behavioral factors are effective in reducing stress; as a result, to change behavior of individuals, in addition to themselves, it is necessary to pay attention to the environment surrounding them and others influencing their behavior.

Keywords: Management, Occupational stress, Nurses, critical care unit, Health Belief Model

Paper Type: Research Article.
\end{abstract}

Citation (Vancouver): Khazar N, Jalili Z, Nazary Manesh L. The Effect of Educational Intervention Based on Health Belief Model on Nurses' Stress Management in Intensive Care Units. Iran J Health Educ Health Promot. Winter 2020;7(4):300311. [Persian]

Citation (APA): Khazar N., Jalili Z., Nazary Manesh L. (Winter 2020). The Effect of Educational Intervention Based on Health Belief Model on Nurses' Stress Management in Intensive Care Units. Iranian Journal of Health Education \& Health Promotion., 7(4),300-311. [Persian]

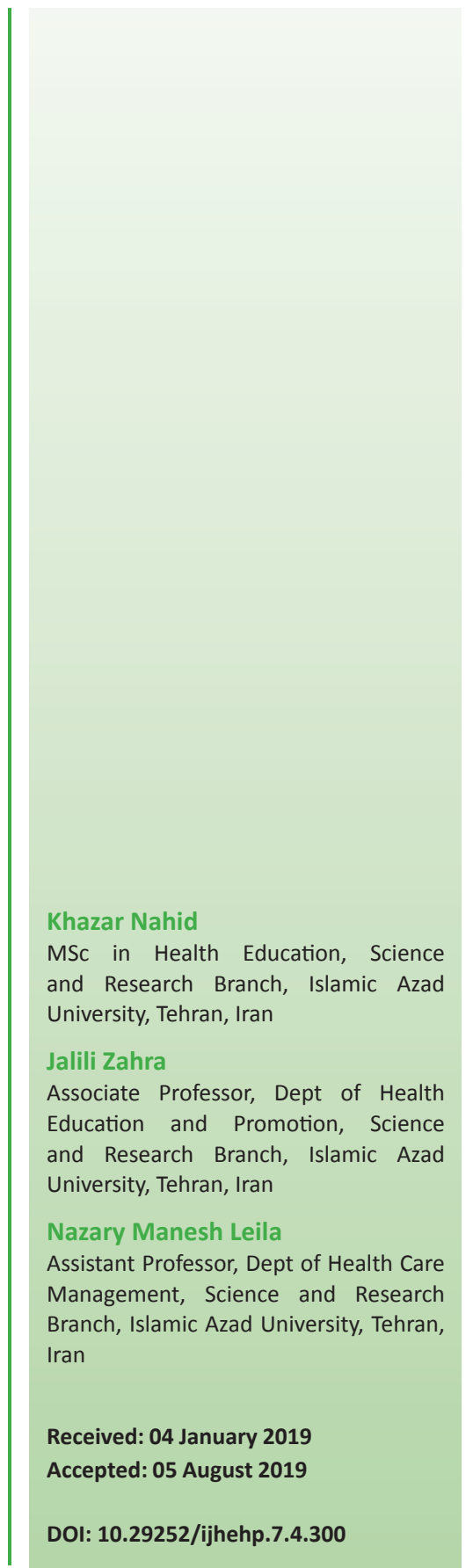




\section{تاثير مداخله آموزشى مبتنى بر مدل اعتقاد بهداشتى بر مديريت استرس شفلى يرستاران بخشهاى مراقبت ويزٔه}

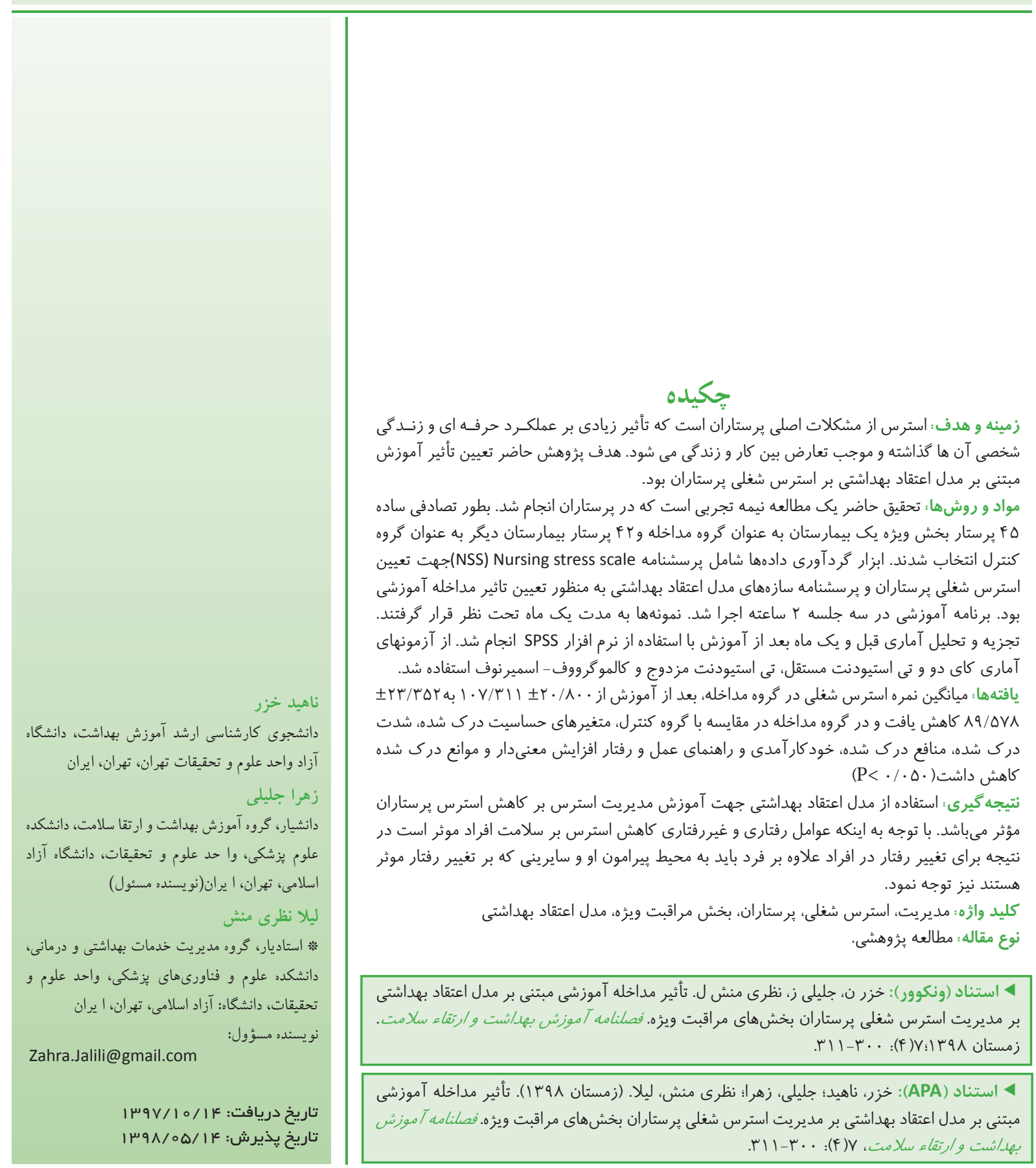


مىشود. بررسىها در ايران نشان داده است كه يرستاران تطابق

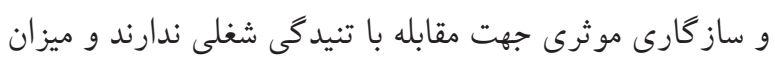

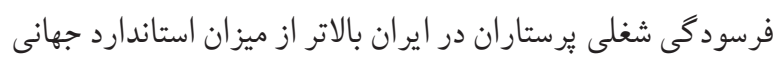

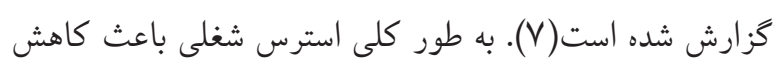

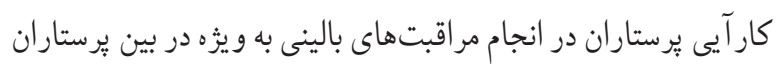

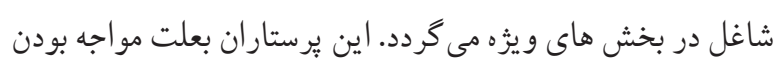

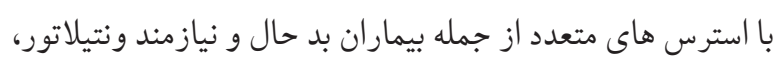

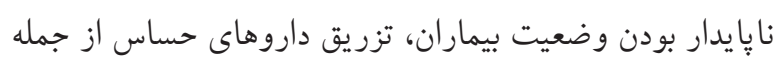

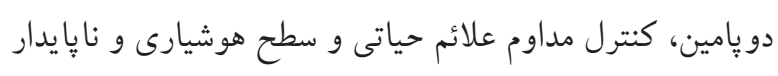

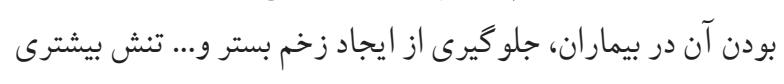

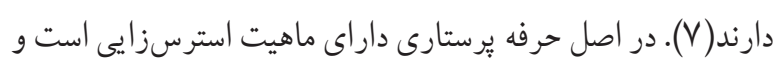

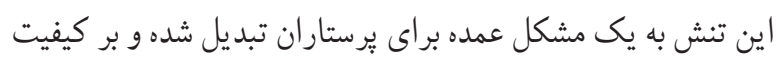

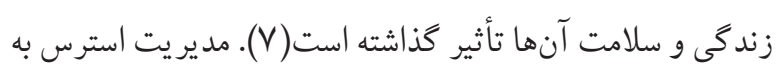

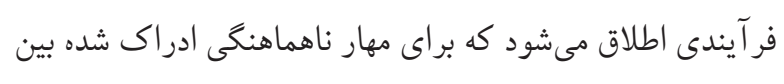
ملزومات و منابع در يك موقعيت استرسزا جهت كنار آمدن استفاده

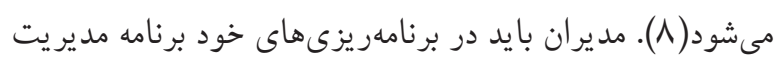

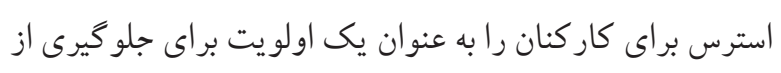
فرسودكى آنان قرار دهند. در اين راستا مديريت استرس توانائي

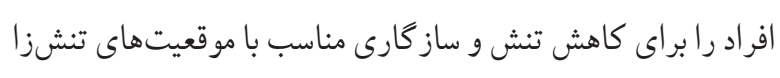
افزايش مىدهد. بعضى از راهبردهاى مقابله با استرس عبارتند

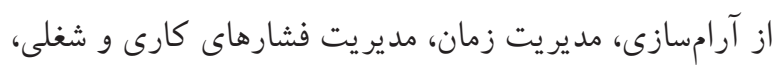

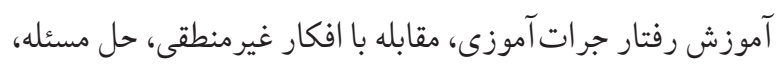

ورزش و تغذيه مىباشد(م).

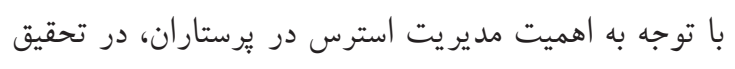

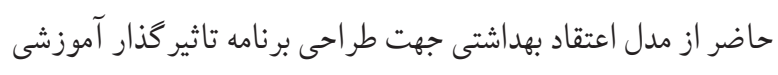

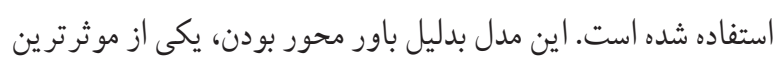

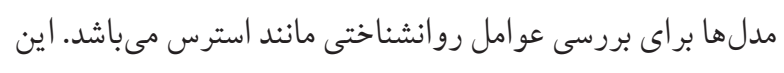

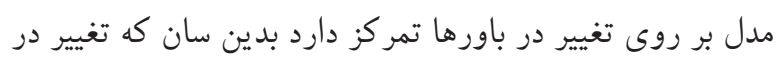

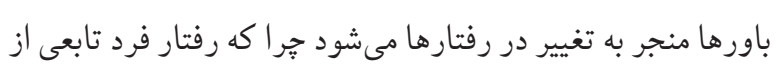
دانش و نكرش اوست (9).

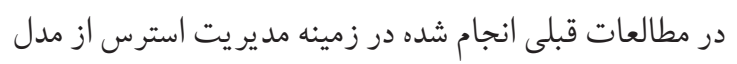

استرس به مجموعهُ واكنشهاى عمومى انسان نسبت به عوامل ناسازگار و بيش بينى نشده داخلسى و خارجى اطلاق مي گرددد. بدين

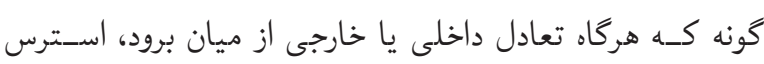
بديـد مى آيـد (1).

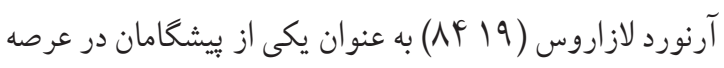

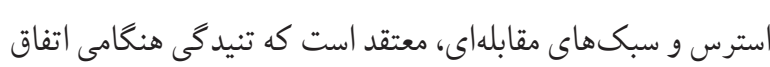
مى افتد كه نيازهايى در فرد بوجود آيد كه از منابع ساز گارانه و

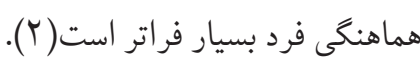
استرس شـغلى عبـارتاست از واســخهـاى هيجـانى آزار

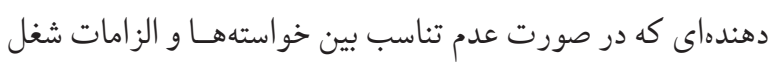

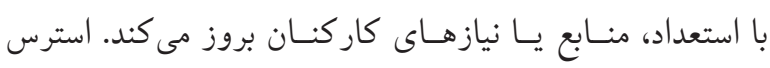

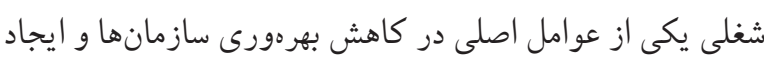
عوارض جسمى و روانى در يرسنل است (ए). طبق تعر يف انستيتو

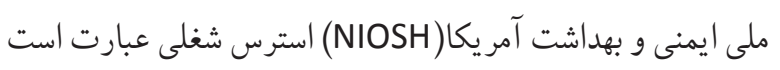
از: ياسخ هاى حسى و جسمى در زمانى كه نيازهاى شغلى با توانايىها،

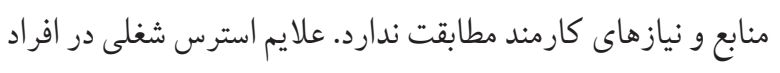

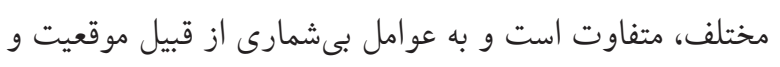

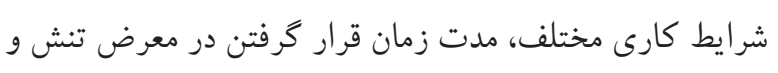

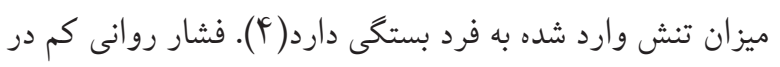
زندگى روزمره باعث تحرى انسان شده واحساس كسالت را از

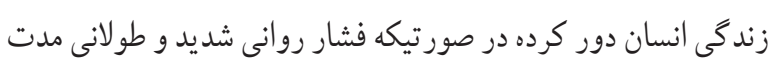

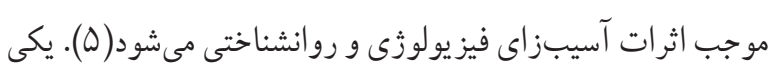
از مهمتر ين منابع ايجاد كننده تنش در زندكى هر فرد شاغل، شغل وى مى باشد. بر طبق تعريف كو ير، تنش شغلى نتيجه كنش متقابل

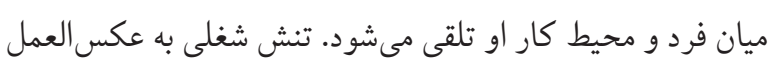

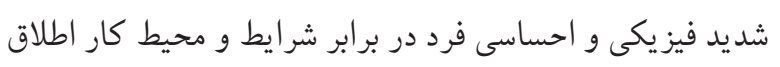
مى شود (9) .

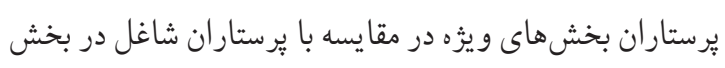
هاى عمومى، با استرس بيشترى مواجه هستند كه آكاهى و اقدام مناسب سبب افزايش بهداشت روانى و رضايت شغلى اين گروه 
سازههاى مدل اعتقاد بهداشتى و همجنين مقياس استرس بِرستارى استاندارد شده( • (1) بكار كرفته شد.

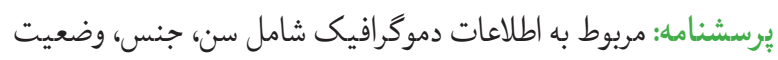
تاهل، مقطع تحصيلى، سابقه كار، بخش كارى و بيمارستان محل

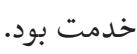

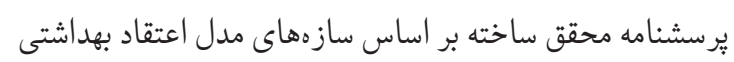

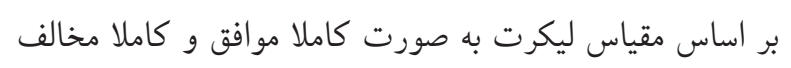
براى سازههاى مدل اعتقاد بهداشتى تنظيم شد.

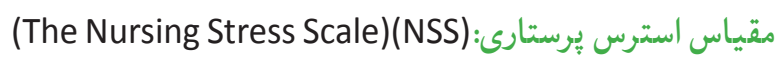
توسط گرى تافت و اندرسون در سال 1911 طراحى شده، و ميزان

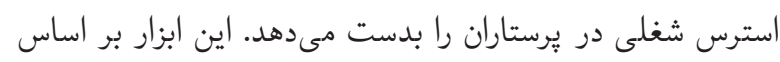

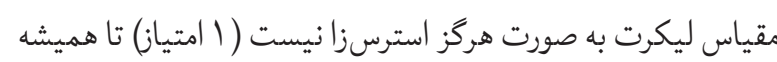

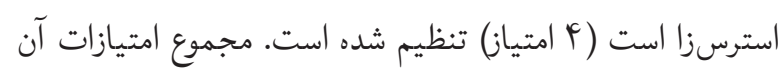

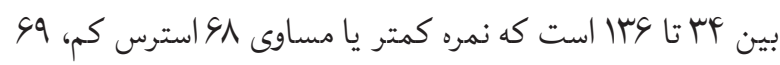

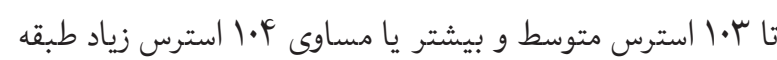
بندى مىشود. اين ابزار شامل ع M عبارت است كه در V حيطه:

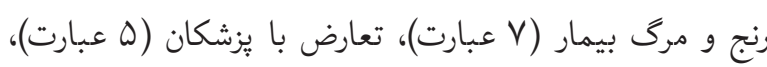

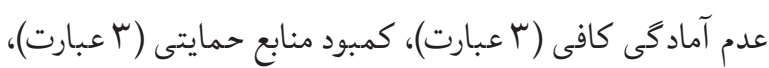

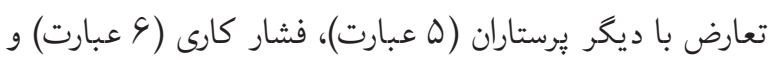

عدم اطمينان از درمان (ه عبارت) تنظيم شده است ( •l).

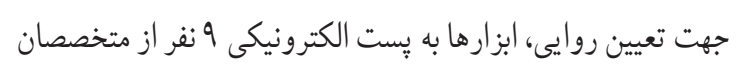

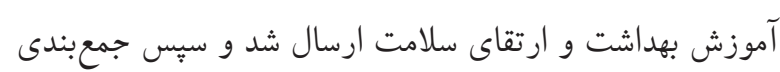

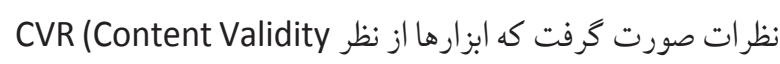
·/ $/ \Lambda=$ (CVI ( Content Validity Index و • / / ) =(Ratio

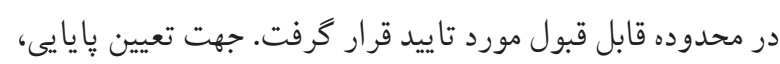

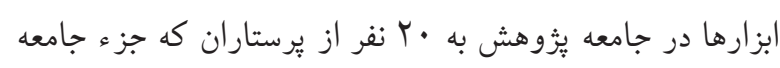

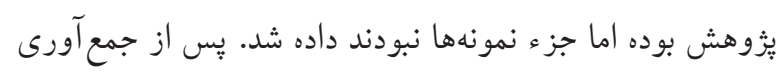

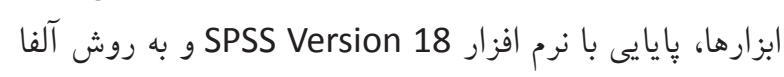

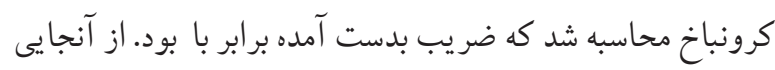

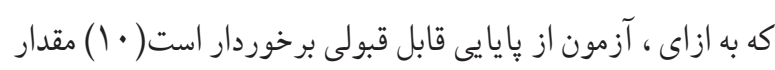

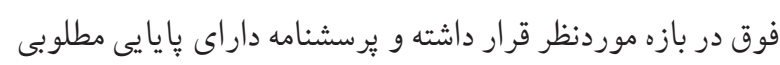

برسيد استفاده شده است (F)، • (1) كه در آنها بر عوامل بيرونى در

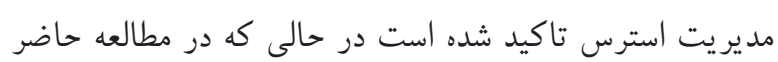

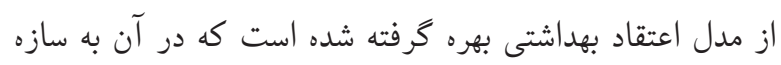

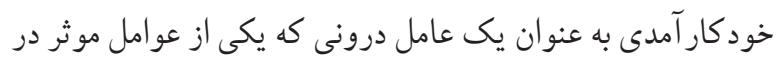

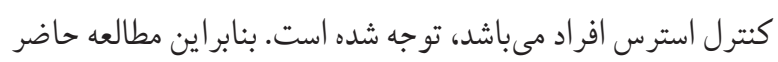
با هدف تعيين تاثير مداخله آموزشى مبتنى بر مدل اعتقاد بهداشتى توردي

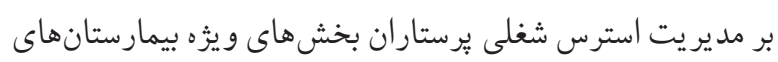

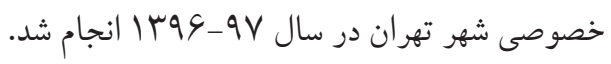

\section{روش تحقيق}

مطالعه حاضر يك مطالعهى مداخلهاى از نوع نيمه تجربى قبل و وكيى

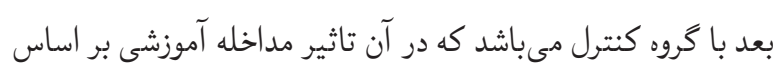

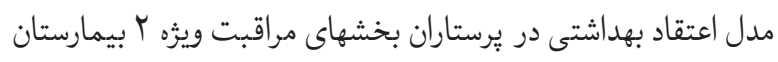
خصوصى شهر تهران سنجش شده است.. با توجه به مطالعه مشابه

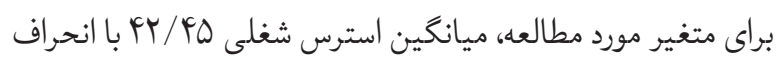

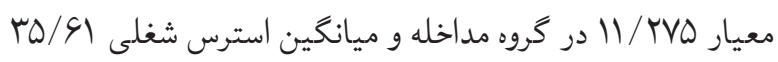

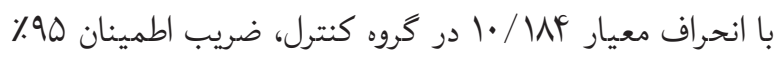

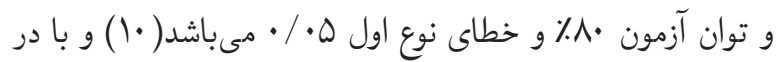

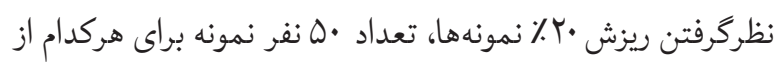

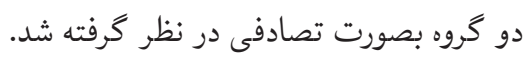

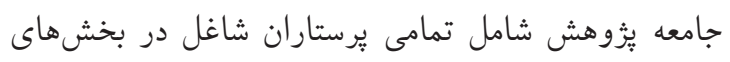

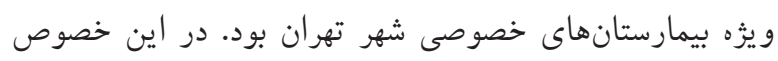

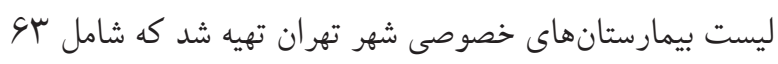

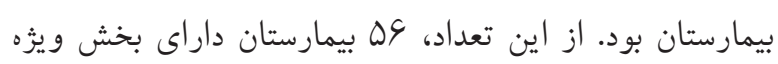
بودند كه به صورت تصادفى بيمارستان پارسيان به عنوان مداخله

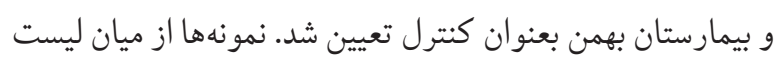

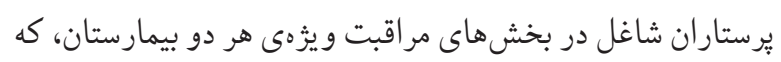

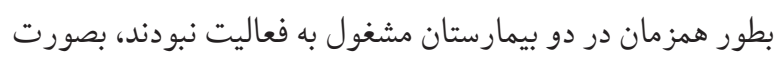
تصادفى ساده انتخاب شدند. در اين مطالعه سه ابزار اندازهكيرى شامل برسشنامنامه مربوط

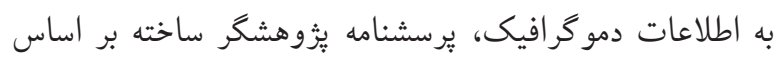


تعيين شده در جلسات آموزشى شركت كنند. همجنين با توجه به جرخشى بودن شيفتها و يا احتمال مرخصى رفتن برستارانى كه در

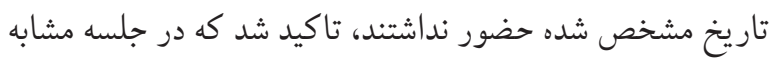
كه براى بخش ويزه ديخر بر گزار مىشود شر كت كنند. جلسات

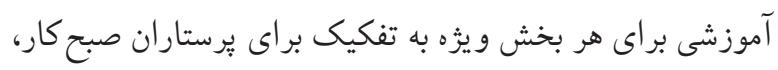

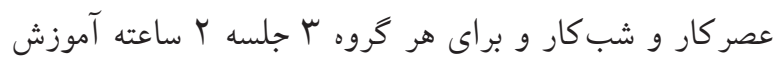

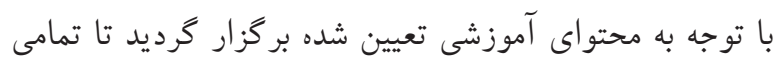

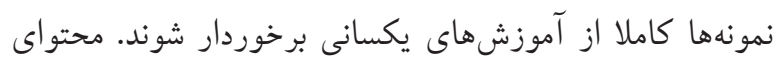

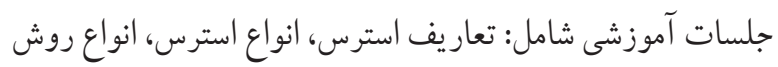
هاى مديريت استرس، روش نوشتن موارد استرس زا، نحوه انجام

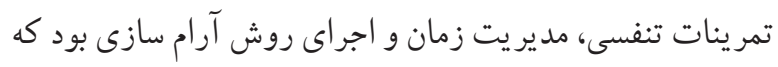

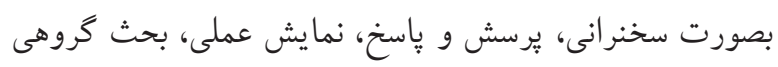

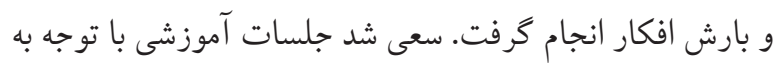

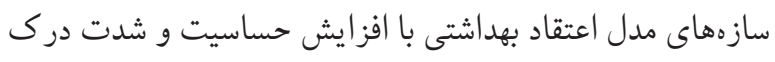

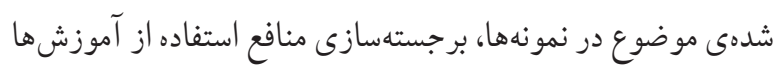

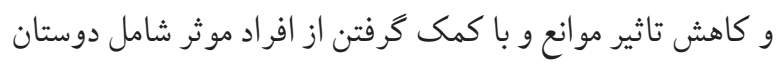
و همكاران و حضور مسئولين بيمارستان در جلسات به تغيير رفتار

$$
\text { و افزايش مدير يت استرس منتهى شود. }
$$

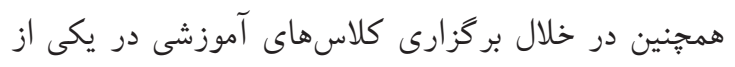
شبكهاى مجازى(واتس آب) گروهى تشكيل شد كه مطالبى در

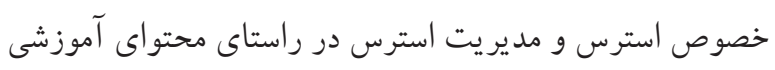

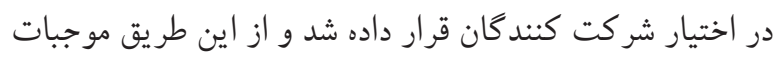

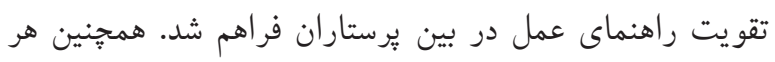

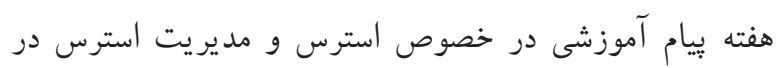

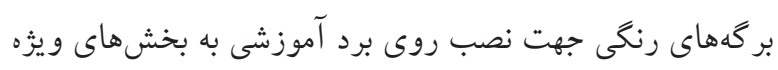

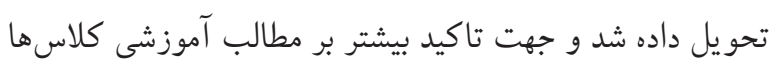
يمفلت مديريت استرس تهيه و به تعداد نمونهها تحويل افر اد داده

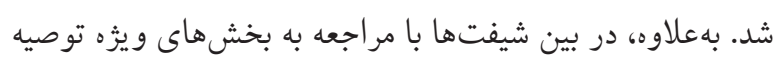

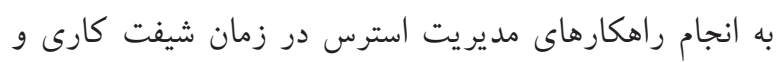
استراحت شد. در خصوص انجام تكنيكهاى تنفسى و آرامسازى

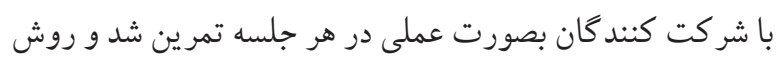

مى باشد. پِس از تاييد روايى و يايايى ابزارها و هماهنكى با رياست

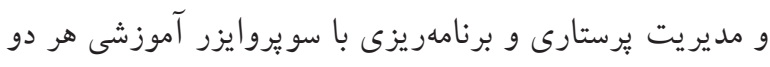

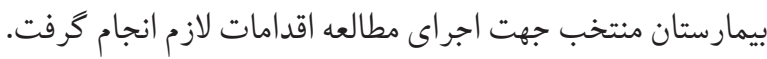
بخش هاى CCU، ICU، NICU بعنوان بخش منتخب انتخاب شد و از

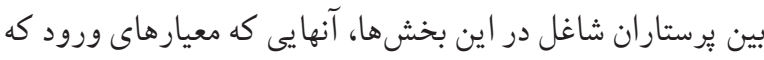

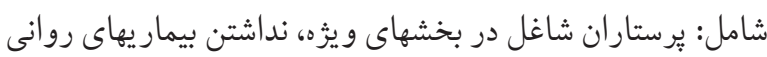

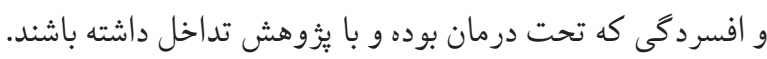

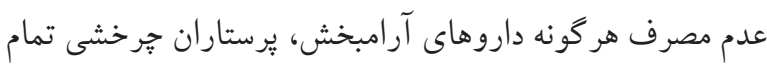

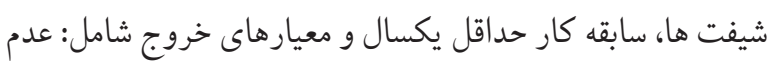
تكميل فرم رضايت آكاهانه، عدم حضور بيش از يك جلسه در كلاس بلاس

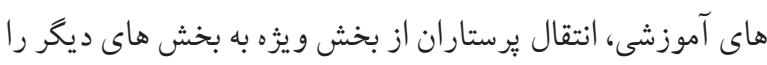

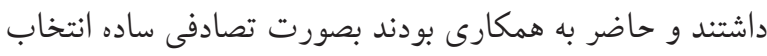
شدند. به شر كت كنند گان در خصوص محرمانه بودن اطلاعات و عدم

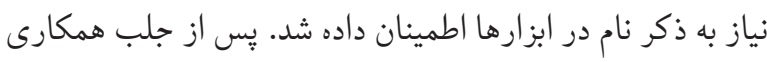

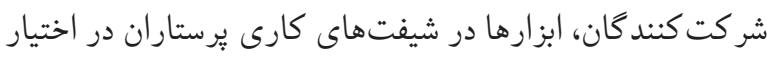

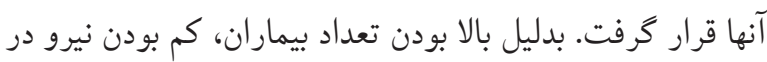

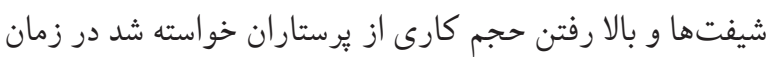

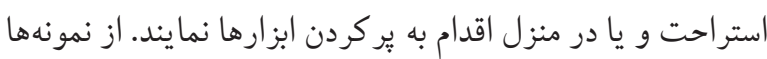

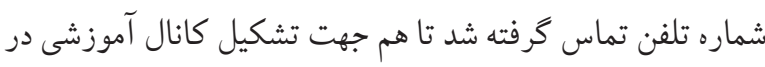

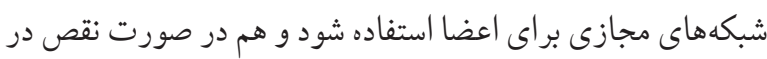

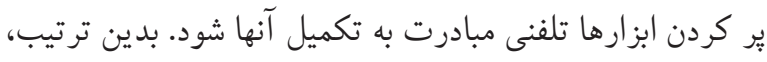
جمع آورى دادهها حدودا يكماه بطول انجاميد. بعد از ارزيابىهاى اوليه و كدبندى، با استفاده از نرمافزار بهار بهول دادههاى حاصل از ييش آزمون مورد تجزيه و تحليل قرار كرفت.

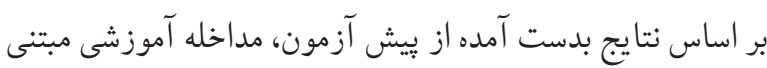

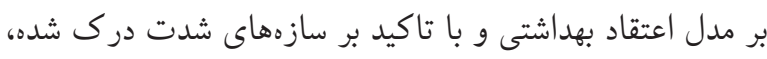

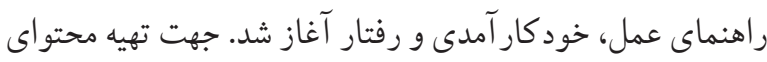

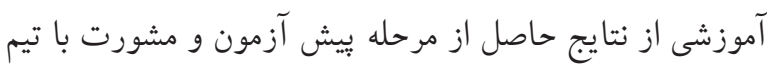

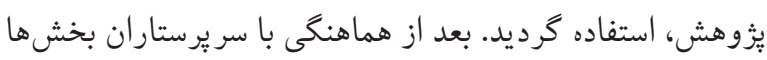

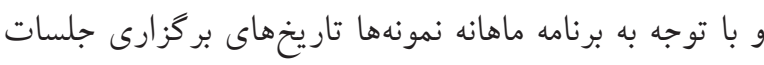

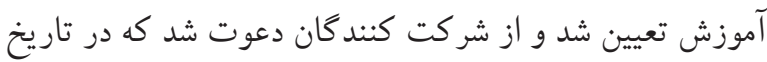


براى مقايسه متغيرهاى دمو گرافيك در دو گروه مداخله و

كنترل از آزمون كاىدو استفاده شد (جدول ()

جدول ا. مقايسه متغيرهاى دموَّرافيك در دو گروه مداخله و كنترل

\begin{tabular}{|c|c|c|c|}
\hline مقايسه & & درجه آزادى & متغير \\
\hline همگن & $\cdot / 1 \mathrm{~F} \Delta$ & r & رده سنى \\
\hline همخن & $\cdot / F \wedge F$ & 1 & جنسيت \\
\hline همخن &.$/ 111$ & 1 & وضعيت تأهل \\
\hline همخن & . / Fro & 1 & سطح تحصيلات \\
\hline همخن & $\cdot / V F \wedge$ & r & سطح تحصيلات همسر \\
\hline همخن & ./Aro & 1 & سمت در بخش \\
\hline همكن & ./Ars & r & نوبت كارى \\
\hline همخن & $\cdot|r s|$ & r & تعداد شبكارى در ماه \\
\hline همخن & $\cdot / r \cdot r$ & f & نام بخش \\
\hline همخن &.$/ . s q$ & 1 & دوره كار در بخش ويزه \\
\hline
\end{tabular}

نتايج بيان شده در جدول يك نشان مىدهد كه گروههاى مداخله

و كنترل در تمامى متغيرهاى دمو گر افيك همكن مىباشند. جهت بررسى سازههاى مدل در ابتدا براى تصميم گيرى در مورد

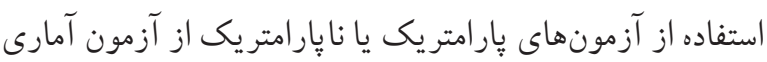
كولمو گروف - اسميرنوف استفاده شده است. نتايج حاصل از اين آزمون آمارى در جدول ب ارائه شده است.

جدول r. توزيع شركت كنند بهداشتى در دو كروه

\begin{tabular}{|c|c|c|c|c|}
\hline \multicolumn{2}{|c|}{ كروه كنترل } & \multicolumn{2}{|c|}{ كروه مداخله } & \multirow[b]{2}{*}{ متغير } \\
\hline آزّمون يس & آزيش & آزّمون & آزيش & \\
\hline$\cdot / F r \cdot \Delta$ & $\cdot / \wedge ૬ \wedge \Lambda$ & - / TFST & ·/^९q. & حساسيت دركشده \\
\hline ש & $\cdot / \mathrm{IVT}$. & $\cdot|S| \Delta F$ & $\cdot / r \Delta \cdot q$ & شدت دركشده \\
\hline$\cdot / 09 \wedge \mathrm{V}$ & $\cdot|\wedge| \wedge \mid$ &.$/ 1 \wedge 9 \mu$ & $\cdot / r q . q$ & منافع درك شده \\
\hline.$/ \cdot \Delta r \Delta$ & $\cdot / \cdot 0$. &.$/ .9 \wedge \Delta$ &.$/ r 990$ & موانع دركشده \\
\hline.$/ 19 \wedge \Delta$ & . NATS & $\cdot / 1 \wedge \Delta S$ &.$/ 1901$ & خود كار آمدى \\
\hline$\cdot / F \mid r V$ & .1 .911 & r &.$/ 9094$ & راهنماى عمل \\
\hline$\cdot / \mathscr{A} \cdot r V$ &.$/ 9 \cdot 9 r$ & $\cdot / \Delta S T V$ & ./TVIV & $\begin{array}{c}\text { رفتار (مديريت) } \\
\text { استرس) }\end{array}$ \\
\hline
\end{tabular}

ايفاى نقش با مشاركت خودشان جهت اجرا براى ديگر اعضاء و تمرين مجدد استفاده شد. تمام مطالب آموزش داده شده در جزوهاى با عنوان مديريت استرس در اختيار يرستاران بخشهاى مراقبت ويزه گذاشته شد كه در صورت تمايل به مرور مطالب دسترسى داشته باشند. يك ماه يس از يايان جلسات آموزش از نمونهها در كروه مداخله و كنترل پِ آزمون بعمل آمد كه برخى از شر كت كنند گان از ير كردن فرمهاى يرسشنامه امتناع كردند و تعدادى هم به دليل استعفا و يا تغيير بخش از بخش ويزه به عادى از نمونها خارج شدند و در نهايت تعداد D\& ابزار از گروه مداخله در مرحله يس آزمون جمع آورى شد. در گروه كنترل نيز بعد از هماهنكى با مسئولين بيمارستان مربوطه و با همكارى سويروايزر آموزشى بونى همز مان با كروه مداخله از افرادى كه شرايط ورود را داشتند ييش آزمون كرفته شد و يكماه بعد همزمان با گروه مداخله يس آزمون بعمل آمد كه در آنجا هم مشكلات مشابه وجود داشت و تعداد

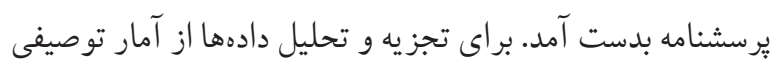

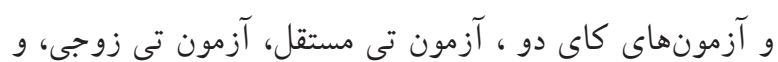
آزمون كولمو گر اف- اسميرنوف استفاده شد. بعد از اتمام يزوهش براى كروه كنترل نيز كلاسهاى آموزش مدير يت استرس بر گزار شد و مواد آموزشى در بين نمونها توزيع شد. يُزوهش حاضر با شناسه IR.IAU.SRB.REC.1397.010 مصوبه اخلاق در يُزوهش را دريافت كرده است.

بافَتها. طبق نتايج حاصله در زمينه اطلاعات دموگرافيك ، گروه مداخله

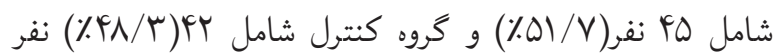
شركت كننده در ڤيزوهش مىباشند. بيشترين فراوانىها در كروه سنى •D- • مال، در جنس زن، افراد متاهل، تحصيلات ليسانس، تحصيلات همسر در مقطع ليسانس، سمت يرستار، شيفت در كردش، كذراندن دوره بخشهاى ويثه تا ابتداى سال اqه| در هر دو گروه، ديده شد. وضعيت استخدامى تمامى NV نفر شركت كننده در اين يزوهش، قراردادى بوده است. 
جدول ب نشان مىدهد كه در تمامى موارد فوق، مقدار از بزركتر براى مقايسه ميانگين نمرات دو گرووه مداخله و كنترل در

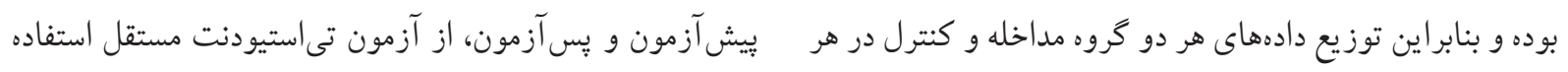

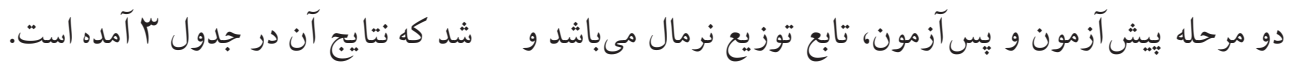
درنتيجه بايستى از آزمونهاى بارامتر يك استفاده نمود.

جدول ّا. نتايج آزمون آمارى تى - استيودنت مستقل در مراحل يِيش آزمون و پِّآزمون

\begin{tabular}{|c|c|c|c|c|c|c|c|}
\hline \multirow[b]{2}{*}{ تفاوت ميانكين } & & \multicolumn{2}{|c|}{ كروه كنترل } & \multicolumn{2}{|c|}{ كروه مداخله } & \multirow{2}{*}{ متغير } & \multirow{2}{*}{ مرحله } \\
\hline & & |نحراف معيار & ميانگين & |نحراف معيار & ميانغين & & \\
\hline خير ير & $\cdot / v \cdot r$ & $F / G r \mid$ & $r N / .90$ & $F / r \wedge l$ & TV/ATt & حساسيت درك شده & \multirow{8}{*}{ بيش آزمون } \\
\hline خير ا & . /qFr & 1/9s & $\mid q / \ldots$ & $r / \cdot V r$ & $\mid r / 9 \vee \wedge$ & شدت درك شده & \\
\hline خير & . $/ F T F$ & $\Delta / \cdot \Delta$. & rN/rMN & $F / I f r$ & YN/ASV & منافع درك شده & \\
\hline خير & ת & $r / q \cdot V$ & $r \cdot / \Delta T F$ & r/VRr & $r Y / .9 V$ & موانع درك شده & \\
\hline خير & ./А१५ & $F / v 9 \Delta$ & $r \cdot 10$. & r/ANI & $r \cdot / \uparrow \ldots$ & خود كار آمدى & \\
\hline خير &.$/ 11 \pi$ & $s / r s q$ & $r \cdot / \Delta r F$ & $\Delta / r q q$ & IN/qRT & راهنماى عمل & \\
\hline خير & . /OFq & F/sसG & $r \Delta / \Lambda \Delta V$ & f/ors & rG/rAq & رفتار (مديريت & \\
\hline خير & $\cdot / r \Delta F$ & $r \Delta / q \mid r$ & $1 \cdot V / 9 \vee 4$ & $r \cdot / \Lambda .$. & $1 \cdot V / T 11$ & NSS & \\
\hline بلى بلى & . & $r / 9 \Lambda \Lambda$ & rN/ץNI & r/YIS & r & حساسيت درك شده & \multirow{8}{*}{ يس آزمون } \\
\hline 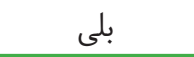 & . & $r / \cdot V F$ & If/Frq & $r / r q s$ & $\mathrm{IV} / \ldots$ & شدت درك شده & \\
\hline بلى بلى & r./. & $0 / 09$. & rN/sq. & $\mu / 1 .$. & $r \cdot / 9 \mu \mu$ & منافع دركشده & \\
\hline خير &.$/ 111$ & $r / \Delta \Delta \Delta$ & $r \cdot / r \mu \Lambda$ & $r / F V r$ & $r \cdot / \Lambda \& V$ & موانع دركشده & \\
\hline بلى & $\cdot / \cdot r V$ & $\boldsymbol{r} / \cdot \boldsymbol{r}$. & rI/rAS & $r / \wedge \vee I$ & Tr/GKT & خود كار آمدى & \\
\hline بلى & $\cdot / \cdot V$ & $9 / 994$ & rI/FOr & r/qur & $r F / r Y \Lambda$ & راهنماى عمل & \\
\hline بلى & . & $\Delta / \Delta H V$ & $r G / Y \mid r$ & $r / \cdot F r$ & سזו/ו & رفتار (مديريت & \\
\hline 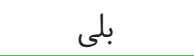 & . & $r \Delta / \Lambda \cdot G$ & $1 \cdot Y / \Delta Y r$ & $r \mu / \mu \Delta T$ & $\wedge ৭ / \Delta \vee \wedge$ & NSS & \\
\hline
\end{tabular}

مطابق جدول ب در مرحله بيش آزمون مقايسه اختلاف ميانگين بر اساس جدول أل، نتايج نشان داد كه ميانگين تمامى متغيرها

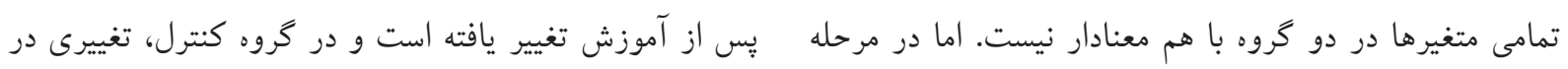

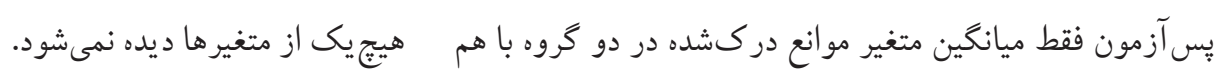

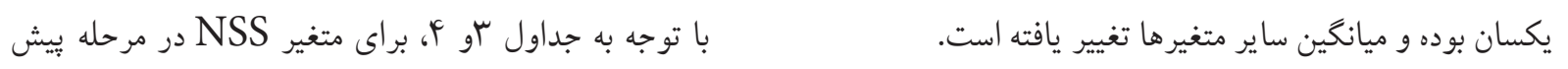

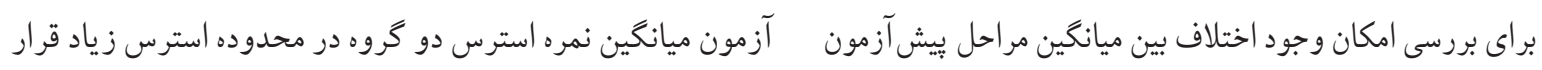

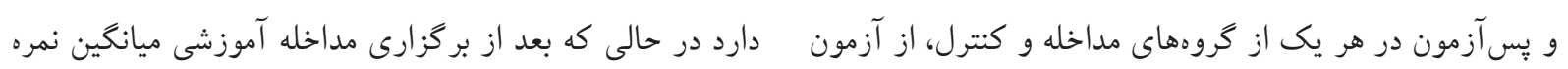

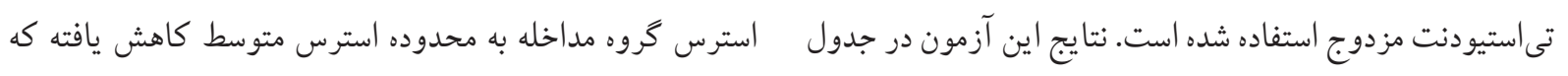

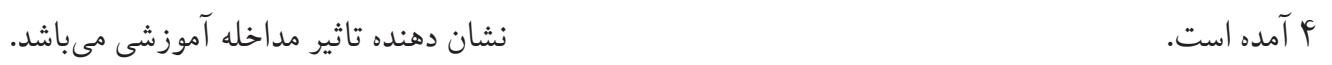


جدول عا: نتايج آزمون آمارى تى - استيودنت مزدوج در گروههاى مداخله و كنترل

\begin{tabular}{|c|c|c|c|c|c|}
\hline آيا ميانگين تغيير يافته است؟ & & ميانگين يسآزمون & ميانكين بيش آزمون & متغير & كروه \\
\hline بلى & . & س & rV/ATr & حساسيت درك شده & \multirow{8}{*}{ كروه مداخله } \\
\hline 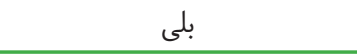 & . & $\mathrm{IV} / \cdots$ & $\mid r / 9 \vee \wedge$ & شدت درك شده & \\
\hline 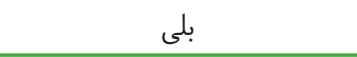 & $\cdot / \cdots 9$ & r. & rN/ASV & منافع دركشده & \\
\hline 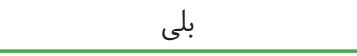 & $\cdot$ & $r \cdot / \Lambda S V$ & $r I / . S V$ & موانع درك شده & \\
\hline 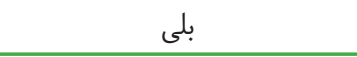 & $\cdot / \cdot r$ & rr/STr & $r \cdot / \uparrow \ldots$ & خود كار آمدى & \\
\hline 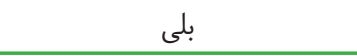 & . & rF/rVA & س & راهنماى عمل & \\
\hline 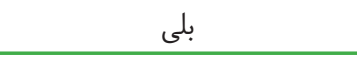 & . & سזו/וץ & $r \varepsilon / r \wedge q$ & رفتار (مديريت استرس) & \\
\hline 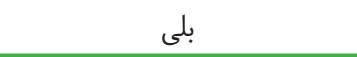 & . & $\wedge ৭ / \Delta \vee \wedge$ & $1 \cdot V / \mu 11$ & NSS & \\
\hline خير & ·/VAS & rN/rNI & $r \Lambda / \cdot 90$ & حساسيت دركشده & \multirow{8}{*}{ كروه كنترل } \\
\hline خير & $\cdot / \mu r \mu$ & If/Arq & $\mid f / \cdots$ & شدت درك شده & \\
\hline خير & $\cdot / 991$ & r^/ৎq. & 广N/rイ & منافع درك شده & \\
\hline خير & . / smp & $r \cdot / r \mu \Lambda$ & $r \cdot / \Delta r F$ & موانع دركشده & \\
\hline خير & $\cdot / 4 \mid \wedge$ & rI/rAS & $r \cdot / 0 \cdots$ & خود كار آمدى & \\
\hline خير & $\cdot / 018$ & $r l / F \Delta r$ & $r \cdot / \Delta r r$ & راهنماى عمل & \\
\hline خير & $\cdot / V \& q$ & $r s / r \mid r$ & $r \Delta / \wedge \Delta V$ & رفتار (مديريت استرس) & \\
\hline خير & . / F T & $1 \cdot F / O Y F$ & $1 \cdot V / 9 V 4$ & NSS & \\
\hline
\end{tabular}

بهداشت بر اساس مدل اعتقاد بهداشتى بر رفتارهاى بيشگيرى كننده.

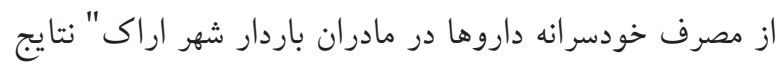

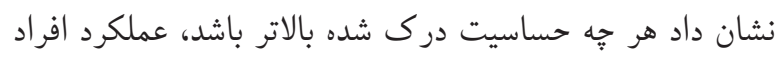

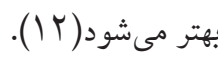

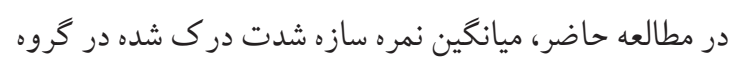

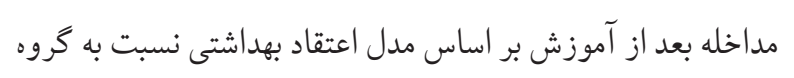

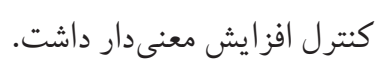

در مطالعهاى كه توسط كارتال و همكاران در تركيه در سال

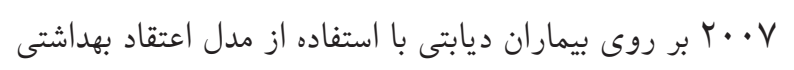

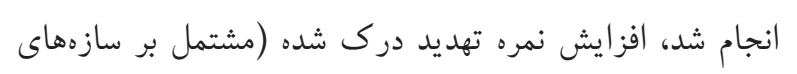

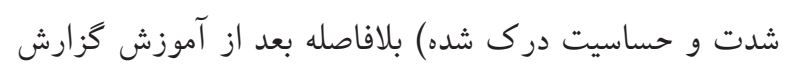

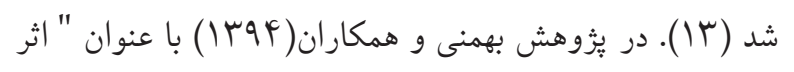
آموزش مبتنى بر مدل اعتقاد بهداشتى بر ميزان مشاركت زنان دمان

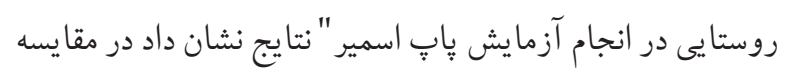

نتايج يثوهش حاضر كه با هدف تاثير مداخله آموزشى بر اساس

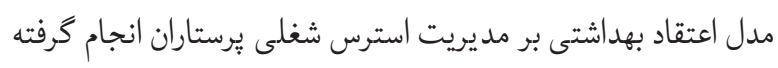

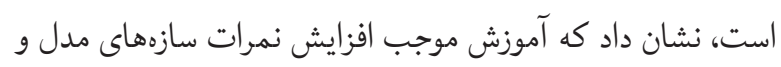

$$
\text { كاهش نمره استرس شده است. }
$$

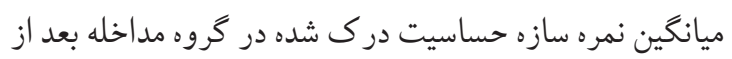
آموزش نسبت به گروه كنترل افزايش معنىدار داشت. اين نتيجه نشان مىدهد كه آموزش بر اساس مدل اعتقاد بهداشتى بر افزايش

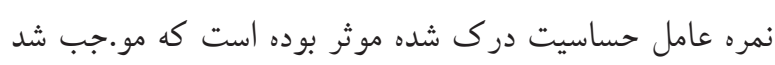
برستاران در نتيجه آموزش خود را حساس در مقابل خطر عوارض درض استرس شغلى بدانند. در يُزوهش ضيايى و همكاران با عنوان "تاثير

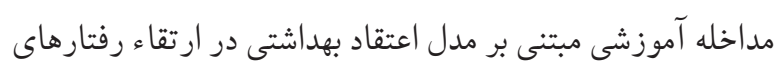
تغذيهاى زنان باردار" پِ از آموزش ميانكين نمره سازه حساسيت درك شده در گروه آزمون به طور معنادارى افزايش يافته بود (11).

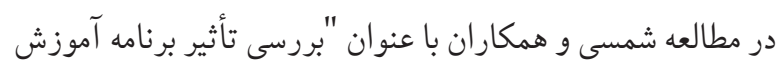


مطالعه شريفى راد نتيجه نشان داد كه بين منافع درك شده و دورى از سيكار كشيدن در بين نوجوانان رابطه مثبت وجود داشت( IV )

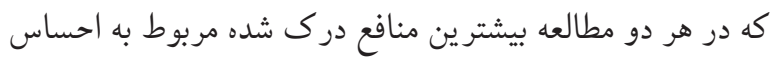

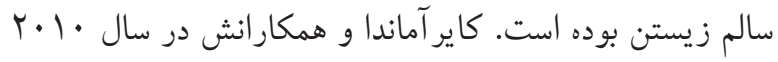

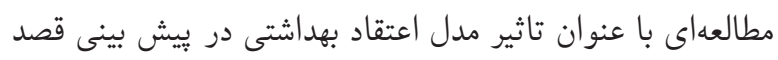

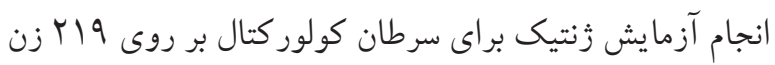

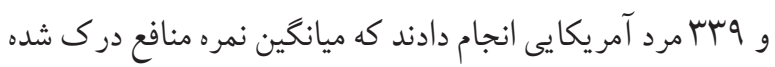

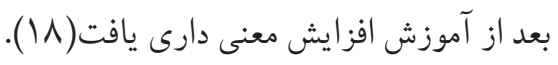

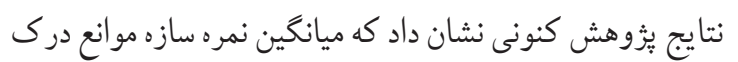

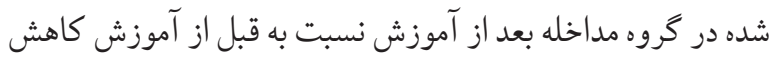
داشت. اما تغيير اين سازه در گروه مداخله نسبت به گروه كنترل

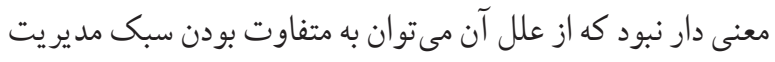

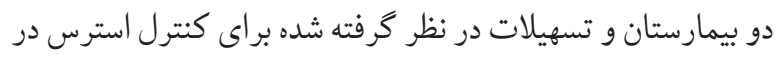

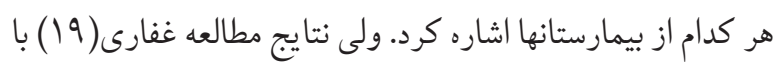
نتايج مطالعه حاضر همخوانى نداشت كه مى تواند علت اين تناقضات در نتـايج، تفاوت در تنوع انسواع موانع درك شده از جمله موانع

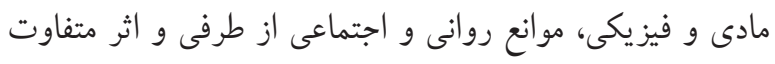

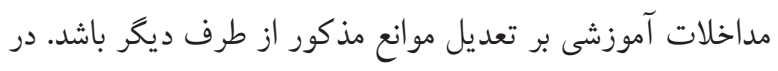

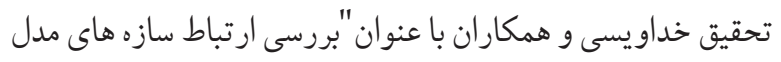

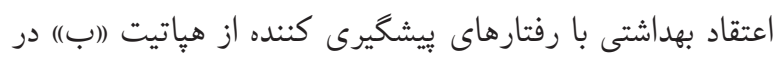

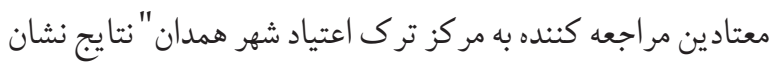

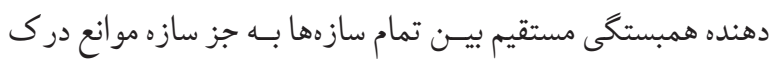

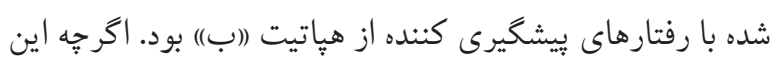

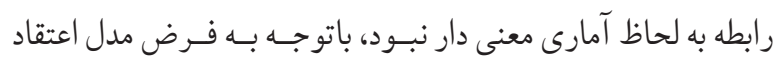
بهداشتى، احتمال اينكه فرد عملى را درخصوص سلامتى خود انجام دهد، به حساسيت درك شده، شدت درى شده و منافع درك شده

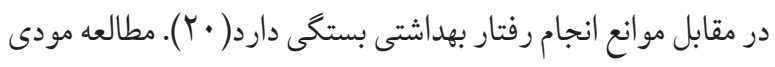
و همكاران با هدف به كار گيرى مدل اعتقاد بهداشتى بر انجام رفتار غربالكرى مامو گر افى نشان داد، در نمرات اجزاى مدل قبل و سه ماه

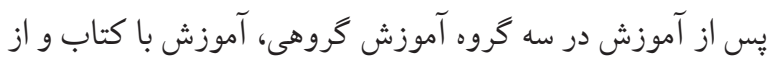

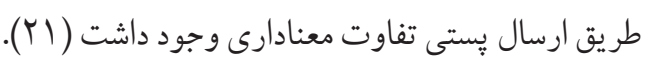

ميانكين نمرات سازههاى مدل در دو گروه آزمون و گروه كنترل در سازه شدت درك شده اختلاف معنى دارى وجود داشت( (IF).

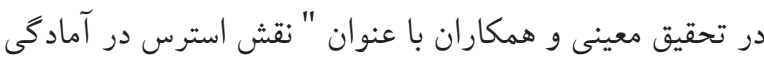

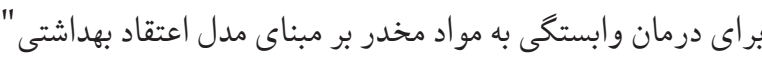

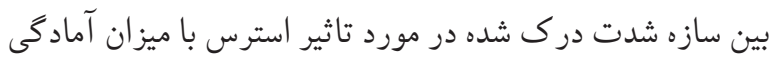

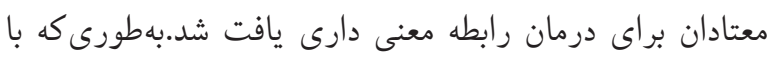

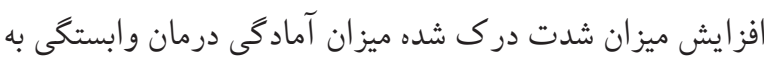

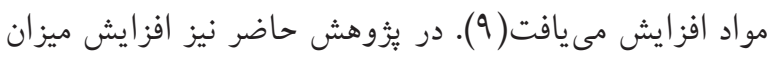

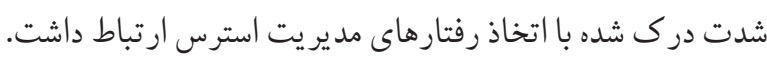

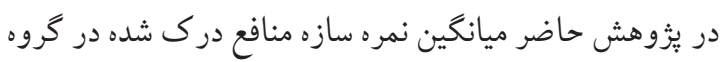

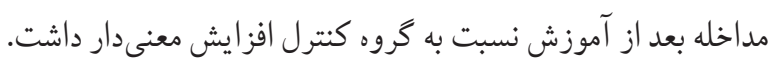

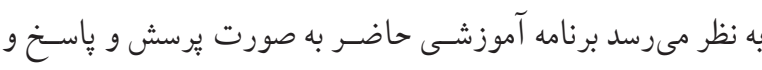
بحـث كروهـى و انجام عملى روشهاى مديريت استرس توانسـته

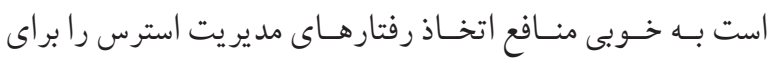

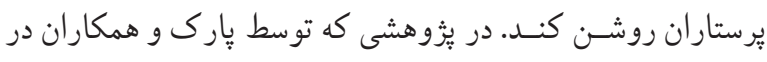
سال ه • • ب با عنوان تاثير يك برنامه متمركز شناخت احساسات براى افزايش مشاركت عمومى در غربالكرى پاٍّ اسمير انجام

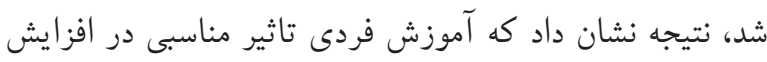

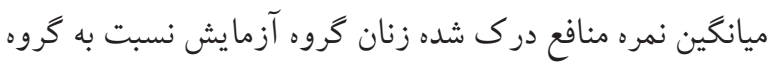

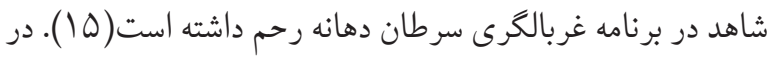
تحقيقى كه توسط رحيمى و همكاران با عنوان "ارتقاى رفتارهاى

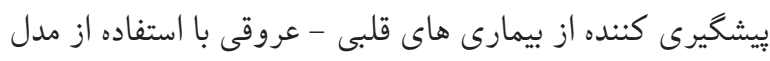

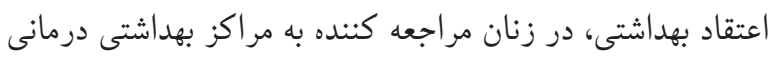

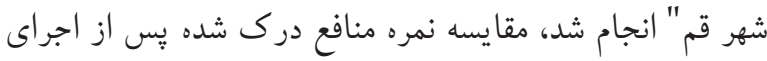

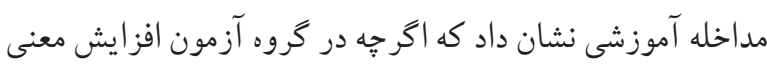

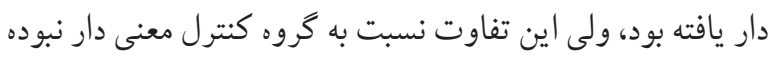

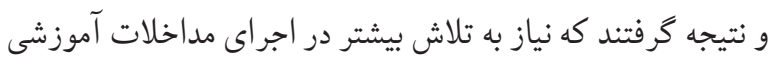

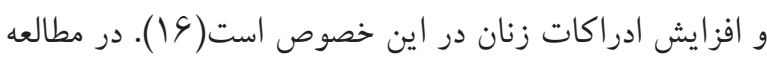
شمسى و همكاران وضعيت درك افراد از منافع مصرف صحيح

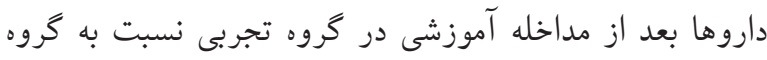

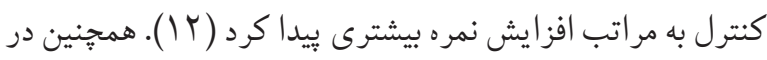


نتايج مطالعه لاعامين و همكارانش با عنوان برنامه آموزش تعليم و تربيت بهداشتى براى آموزش تالاسمى در دانش آموزان

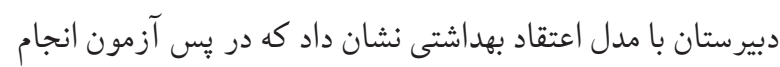

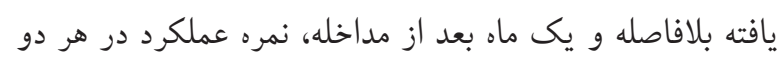

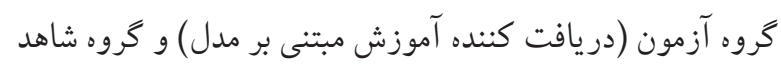

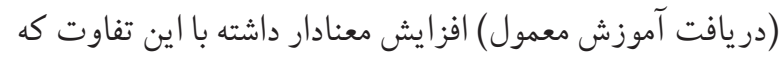
اين افزايش در گروه آزمون بيشتر بوده است (T) (T).

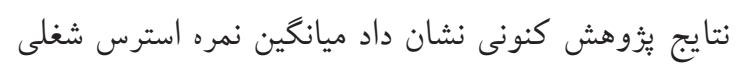
يرستارى در گروه مداخله قبل از آموزش در محدودهه استرس بالا

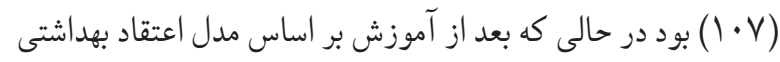
ميانخين نمره استرس شغلى به محدوده متوسط (19) كاهش يافت

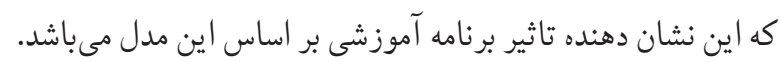

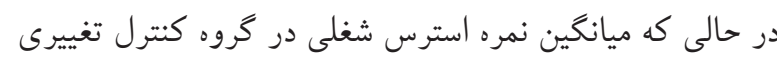
نكرده و در همان محدوده يِيش آزمون باقى مانده است.

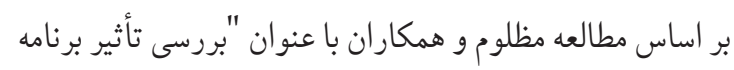

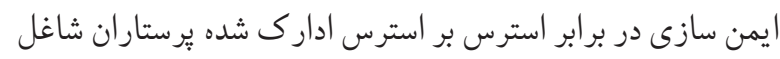

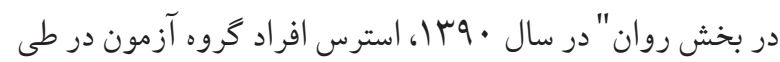

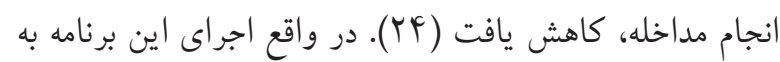

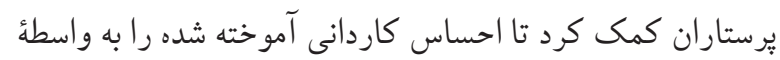
تجارب موفقيت آميز در مقابله با سطوح قابل كنترل استرس در درد خود پيديد آورند و مكانيسم هاى دفاعى آينده نغر شامل مهارتها

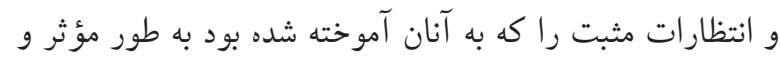

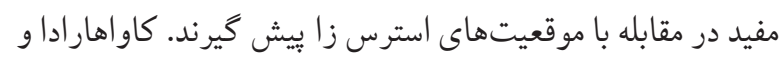

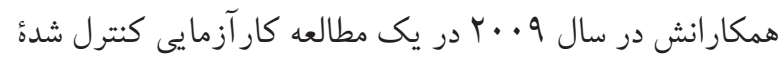

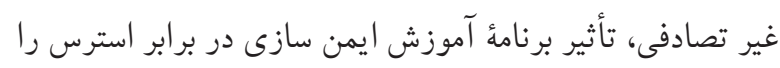

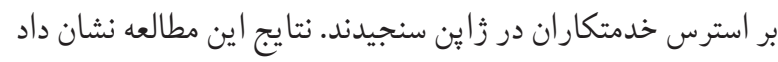

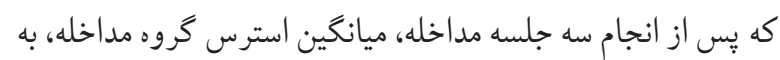

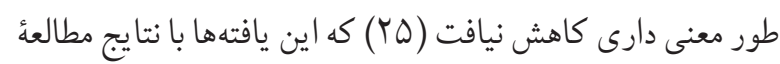

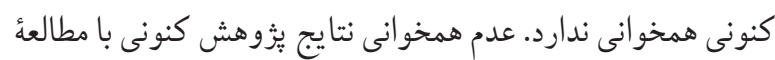

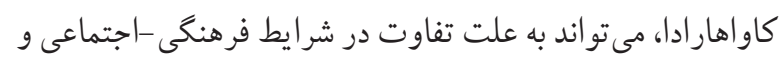
متفاوت بودن موقعيت كارى و زندگى يرستاران با خدمتكاران باشد.
نتايج مطالعه حاضر نشان داد، ميانكين نمره سازه خود كار آمدى

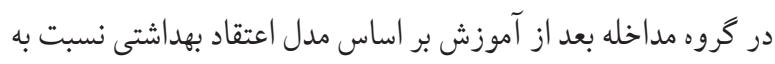
كروه كنترل افزايش معنى دار داشت. خود كار آمدى به عمق اطمينان فرد راجع به كار آيى شخصىاش اشاره دارد كه در اين يُزوهش با با بالا رفتن احساس خود كار آمدى برستاران، اتخاذ رفتارهاى مديريت

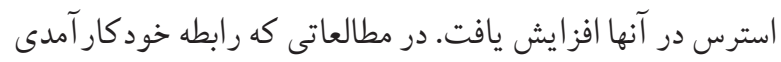

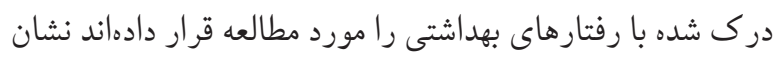

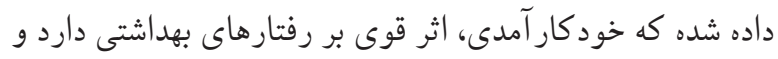

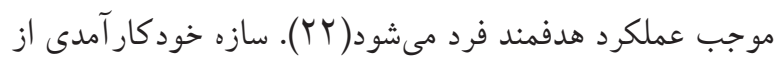
اين جهت كه مىتو اند ارتباط قوى با بروز رفتار داشته باشد، بايد

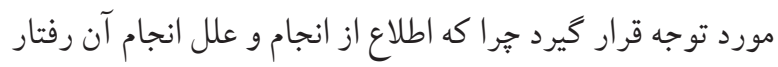

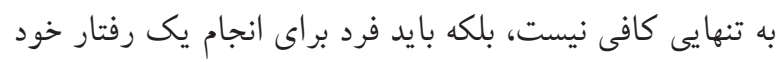

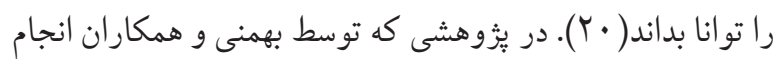
شده است آموزش سبب افزايش خود كار آمدى درك شده در زنان

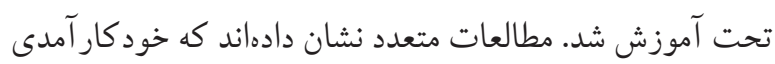
يكى از عوامل بسيار مهم در انجام رفتارهاى بهداشتى است (II (I).

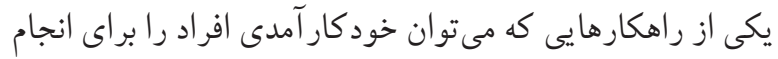
رفتار بهداشتى بالا برد، كاهش موانعى است كه در سر راه انجام اندام

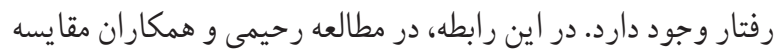

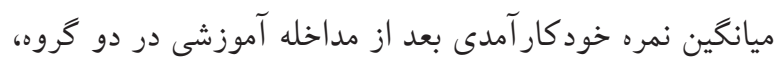

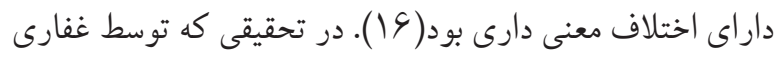

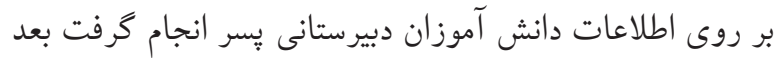

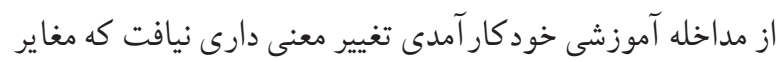
با نتايج تحقيق حاضر بود(19) كه احتمالا بدليل سن پإيين نمونهها و نياز به آموزشهاى مداوم و مستمر در اين خروه سنى مى باشد.

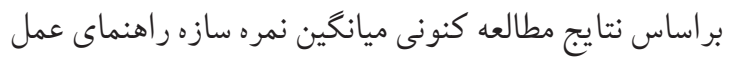

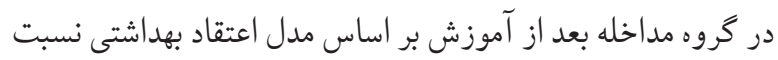

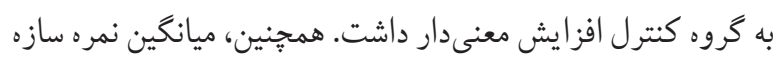

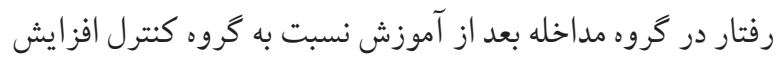

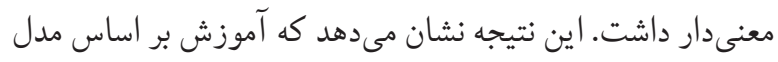
اعتقاد بهداشتى بر افزايش نمره عامل رفتار موثر بوده است. 
كَديد. همجنين نتايج يُوهش نشان داد كه آموزش مديريت استرس بر اساس مدل اعتقاد بهداشتى باعث افزايش معنادار ميانخين نمره رفتار كه همان مديريت استرس بوده و كاهش معنادار ميانگين نمره استرس شغلى در يرستاران گروه مداخله نسبت به گروه كنترل مىشود.

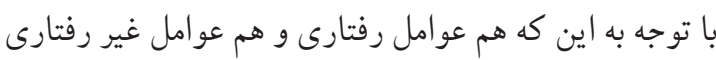
كاهش استرس بر سلامت افراد موثر است در نتيجه براى تغيير

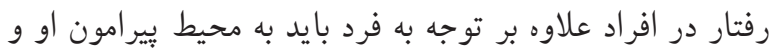

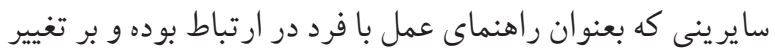

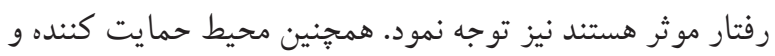

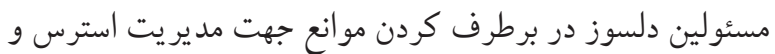
كاهش استرس شغلى نقش بسزايى دارند. تشكر و قدردانى اين يُزوهش حاصل پايان نامه كارشناسى ارشد گروه آموزش

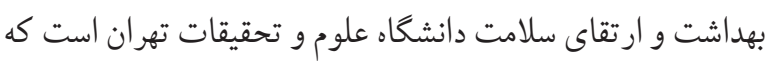

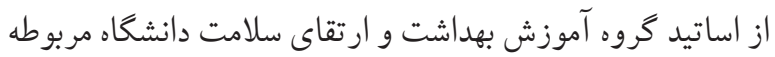

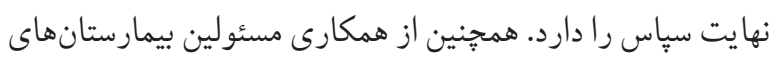

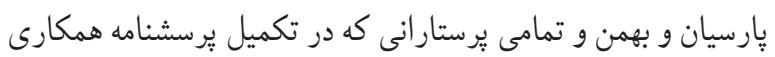
نمودند تشكر مىشود.

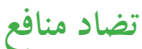
سهم تمامى نو يسند گان در اين مطالعه يكسان است و هيج گونه تضاد منافعى وجود ندارد.

\section{References}

1. Ghasem zadeh, A, Seyed Abas zadeh, M, Hasani, M, Structural modeling of personality traits on stress and job performance considering the mediating effects of individual accountability behavior. Iranian Occupational Health J. 2012.10(2):54-64.

2. Lazarus RS, Folkman S. Stress, appraisal and coping. New York J: Springer 1984: 2(5): 345-65.

3. Murphy LR. Stress management in work stress: A critical review of the health effects. American J health promot 1996; 11(2): 112-35. https://doi.org/10.4278/0890-1171-11.2.112 PMid:10163598

4. Esmailzadeh Gatabi G, Jalili Z, Rabie zadeh,F.The
در تحقيق فتحى و همكاران با عنوان تاثير آموزش ريلكسيشن در كاهش استرس شغلى برستاران مشخص شد كه با درجهى اطمينان 99 درصد خودهيينوتيزم و آرام سازى بيشرونده عضلانى(ريلكسيشن) بر كاهش استرس ناشى از محيط كار (شغلى استرس) تاثير دارد

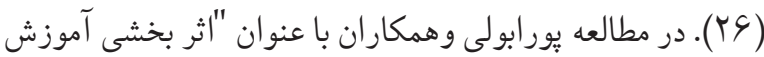

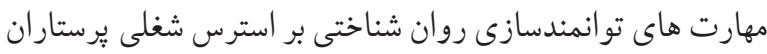
بخش هاى مر اقبت ويزه بيمارستان شهيد رجايى شيراز "ميانكين

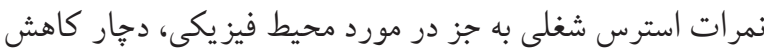

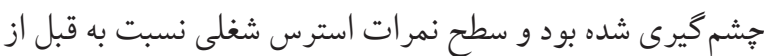

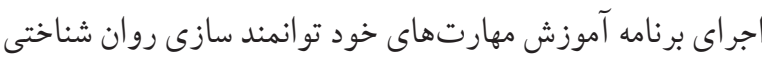

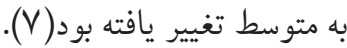

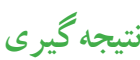

آكاهى از استرس و آموزش راهبردهاى مقابله با استرس، سازگارى افراد را بالا مىبرد و ارزيابى شناختى، نقش شايان توجهى در اين اهني

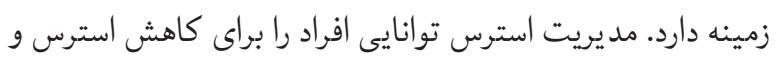

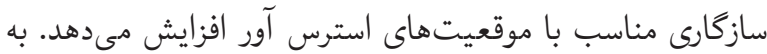

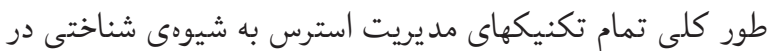

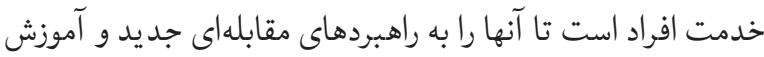

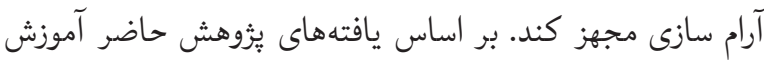
مديريت استرس بر اساس مدل اعتقاد بهداشتى موجب افزايش نمره سازههاى حساسيت درك شده، شدت درك شده، منافع درك شده، خود كارآمدى و راهنماى عمل و كاهش نمره سازه موانع درك شده،

Effect of stress management training based on PRECEDE model on pre- hospital emergency staff occupational tension in Mazandaran university of medical sciences in 2016. HDQ.2017: 3 (1)11-20 https://doi.org/10.29252/nrip.hdq.3.1.11

5. Sobhi-Gharamaleki N, Porzoor P, Aghajani S, Narimani M. Effectiveness of Emotion Regulation Training on Reduction of Anxiety, Stress and Depression Symptoms among University Students. Iran J Health Educ Health Promot. 2015; 3 (1):5-13

6. Saberinia, A, Nekooi moghadam M, Mahmoodi F, Identification of stressors causing dissatisfaction in emergency hospital staff in Kerman 2013, J Payavard 
salamat, 2012, 6(6): 489-497.

7. Pouraboli B, Esfandiari S, Ramezani T, Miri S, Jahani Y, Sohrabi N, Effectiveness of their. teaching skills to reduce stress job psychological empowerment of nursing staff in intensive care units in the center of Shiraz Shahid Rajaee 1392. Journal of Clinical Nursing and Midwifery 2016; 5 (1) :23-35

8. Heshmat H, Behnampour N, Homaei E, Khajavi S. Predictors of fruit and vegetable consumption among female high school students based on PRECEDE model. Iran J Health Educ Health Promot. 2014; 1 (4) :5-14

9. Moeini B, Hazavehei S M M, Shahrabadi R, Faradmal J, Dashti S. Role of stress in treatment readiness of drug dependence based on Health Belief Model. koomesh. 2015; 16 (2) :185-192.

10. Didehvar M, Jalili Z, Zareban I, Bakhshani Noor M, Shahrakipour M, The Effect of Stress Management Education Based on PRECEDE Model on Occupational Stress of Nurses in Hospitals of Iranshahr, Iran, Strides in Develop Med Educ J of Med Educa Develop Center, 2015: 12(3):472 -484

11. Ziaee R, Jalili Z, Tavakoli Ghouchani H. The effect of education based on Health Belief Model (HBM) in improving nutritional behaviors of pregnant women, J North Khorasan Uni Med Sci,2016:8(3),427-437 https://doi.org/10.18869/acadpub.jnkums.8.3.427

12. Shamsi M, Bayati A, Mohamad Beigy A, Tajik R. The effect of health education program based on health belief model on preventive behaviors of drug abuse in pregnant women in Arak (1999), Research J Shahid Beheshti uni med sci, 1999. 4(6), 324-331

13. Kartal A, Ozsoy SA. Validity and reliability study of the Turkish version of Health Belief Model Scale in diabetic patients. Int J Nurs Stud. 2007; 44(8): 1447-58 https://doi.org/10.1016/j.ijnurstu.2007.06.004 PMid:17655849

14. Bahmani A, Gharib A, Rahmani Kh, Ahmadian F, Alizadeh Z, Akhtar B, Effect of Health Belief Model Education on the Participation of Rural Women in Papsmear Test, J nurs educ, September-October 2016, 5(4) :34-40 https://doi.org/10.21859/jne-05045

15. Park S, Chang S, Chung C. Effects of a cognitionemotion focused program to increase public participation in Papanicolaou smear screening. Public Health Nurs 2005;22(4):289-98. https://doi.org/10.1111/j.0737-1209.2005.220404.x PMid:16150010

16. Rahimi T, Shojaei S, Mousavi Miyandashti Z, Amini Z, Khazir Z, Promotion of Preventive Behaviors of Cardiovascular Diseases Using Health Belief Model in Women Referring to Health Centers in Qom, Iran, Qom Uni Med Sci J ,2015; 9(11): 51- 59.
17. Sharifirad GhR, Hazavehei MM, Hasanzadeh A, Daneshamouz $A$. The effect of health education based on health belief model on preventive actions of smoking in grade one, middle school students. Arak Medical University Journal (Rahavard Danesh). 2007; 10(1): 1-8

18. Cyr A, Dunnagan TA, Haynes G. Efficacy of the Health Belief Model for Predicting Intention to Pursue Genetic Testing for Colorectal Cancer. J Genet Counsel. 2010; 19(2): 174-86. https://doi.org/10.1007/s10897-009-9271-7 PMid:19902341

19. Gaffari M, Niknami S, Kazemnejad A, Mirzaie E. Design, Reliability and validity of the Ten-scale HIV prevention in adolescents. J Behboud 2007; 11(1): 36-50.

20. Khodaveisi M, salehikha M, Bashirian S, Karami M, study of Preventive Behaviors of Hepatitis B Based on Health Belief Model among Addicts Affiliated to Hamedan, sci J of Hamadan nursing \& Midwifery faculty, 2016; 24(2): 129137.

21. Moodi M, Norozi E, Rezaeian M, Mostafavi F, Sharifirad Gh. Comparing the effectiveness of Three Educational Interventions based on Health Belief Model on Mammography screening Behaviors in Women above 40 Years in Isfahan. IJHSR. 2013; 9 (4): 385-94.

22. Karimy M, Zareban I, Tabasi A, Taher M, Fayazi N. Beliefs and factors affecting preventive behaviors of HIV transmission in patient's positive HIV, Quarterly Journal of infectious diseases and tropical medicine, affiliated with the society for tropical and diseases, 2016. 21(72). 41-47.

23. Lagampan S, Lapvongwatana P, Tharapan C, Nonthikorn J. Health Belief Model teaching program for thalassemia education in high school students. J Chula Med 2004 Nov; 48(11): 723-735.

24. Mazlom SR, Darban F, Vaghei S, Modarres Gharavi $M$, Kashani Lotfabadi $M$, Shad $M$, The effect of Stress Inoculation Program (SIP) on nurses' Perceived stress in psychiatric wards. Quarterly Journal of Nursing Management, 2012;2(1); 35-43.

25. Kawaharada M, Yoshioka E, Saijo Y, Fukui T, Ueno T, Kishi R. The Effects of a Stress Inoculation Training Program for Civil Servants in Japan: A Pilot Study of a Non-randomized Controlled Trial. Industrial Health. 2009; 47: 173-82. https://doi.org/10.2486/indhealth.47.173 PMid:19367047

26. Fathi $M$, Joodi $M$, Sadeghi A, Sharifi A, Joodi $M$, Poorfereidooni F. Evaluation of effect of relaxation training in nurse's stress reduction. Zahedan J Res Med Sci (ZJRMS) 2011; 13(4):47. 